\title{
Early complications of venous port catheter implantation by a car- diologist: a single centre experience
}

\author{
Bruno Lovreković', \\ Mario Stipinović², \\ Tomislav Letilović1,2, \\ Darko Počanić², \\ Njetočka Gredelj \\ Šimec², \\ Helena Jerkić ${ }^{2}$ * \\ 'University of Zagreb School \\ of Medicine, Zagreb, Croatia \\ 2University Hospital Merkur, \\ Zagreb, Croatia
}

\begin{abstract}
KEYWORDS: port catheter, early complications, cardiologist.
CITATION: Cardiol Croat. 2017;12(9-10):376. | https://doi.org/10.15836/ccar2017.376

*ADDRESS FOR CORRESPONDENCE: Helena Jerkić, Klinička bolnica Merkur, Zajčeva 19, HR-10000 Zagreb, Croatia. Phone: +385-99-4888-576 / E-mail: helenajerkic@yahoo.com

ORCID: Bruno Lovreković, http://orcid.org/0000-0003-3765-1483 • Mario Stipinović, http://orcid.org/0000-0002-1582-1552 Darko Počanić, http://orcid.org/0000-0003-3257-110X • Tomislav Letilović, http://orcid.org/0000-0003-1229-7983 Njetočka Gredelj Šimec, http://orcid.org/0000-0002-3721-2758 • Helena Jerkić, http://orcid.org/0000-0002-1650-4735 IIIIIIIIIIIIIIIIIIIIIIIIIIIIIIIIIIIIIIIIIIIIIIIIIIIIIIIIIIIIIIIIIIIIIIIIIIIIIIIIIIIIIIIIIIIIIIIIIIIIIIIIIIIIII

Objectives: Port catheters are central venous catheters used as therapeutic devices in oncological patients. They are used for the administration of chemotherapeutic agents, antibiotics infusion, transfusion of blood products or parenteral nutrition ${ }^{1}$. Their insertion and their use may be associated with serious complications. Port catheters insertion is usually performed by an oncologist, a radiologists or a surgeon ${ }^{1}$. In our institution a cardiologist implants those devices. The purpose of this study is to determine early complications of port catheter insertion by cardiologists.
\end{abstract}

Patients and Methods: Data from 76 patients with hematological malignancies, who had received a venous port catheter in University Hospital Merkur between October 2013 and May 2017, were collected and analyzed. The port catheter insertion procedure was performed by two cardiologists and all procedures were done through right subclavian venous access under fluoroscopy guidance.

Results: Of the 76 patients, 42 (55.2\%) were females and 34 (44.7\%) males. Mean age was 51 years (range 21-65 years). Total catheter stay time was 897 months and mean time of catheter use was 402 days. A total of 76 port insertion were successful. Pneumothorax was observed in 4 patients (5.2\%). Malposition (catheter tip in the left subclavian vein or internal jugular vein) was observed in $3(3.9 \%)$ patients. Pocket hematoma was observed in 3 (3.9\%) patients. None of these early complications required catheter extraction. Severe arrhythmia, cardiac perforation, thrombosis, hemothorax, catheter dysfunction, pocket infection were not observed in our study.

Conclusion: The implantation of port catheters is a valuable method for long term treatment hematological malignancies. The rate of early complications in our study is comparable to the published data ${ }^{1}$. So, venous port catheters placement can be performed safely by cardiologists.
RECEIVED:

August 12, 2017

ACCEPTED:

September 26, 2017

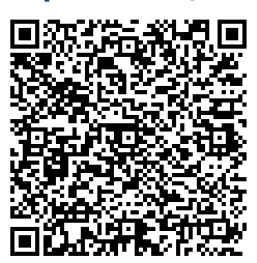

LITERATURE IIIIIIIIIIIIIIIIIIIIIIIIIIIIIIIIIIIIIIIIIIIIIIIIIIIIIIIIIIIIIIIIIIIIIIIIIIIIIIIIIIIIIIIIIIIIIIIII

1. Aziret M, Irkorucu 0, Gokler C, Reyhan E, Cetinkunar S, Cil T, et al. Performance of venous port catheter insertion by a general surgeon: a prospective study. Int Surg. 2015 May; 100(5): 827-835. https://doi.org/10.9738/INTSURG-D-14-00214.1 